\title{
Moralność, przejrzystość i edukacja jako determinanty optymalnego wydatkowania środków publicznych
}

\author{
Integrity, transparency and education as determinants \\ of optimal public spending
}

Streszczenie. Punktem wyjścia do rozpoczęcia badań zaprezentowanych w niniejszym artykule stały się trudności ze skutecznym wdrożeniem budżetu zadaniowego w Polsce. Ponad dwudziestoletnie doświadczenia w tym zakresie nie doprowadziły do efektywnego, skutecznego i gospodarnego wydatkowania środków publicznych. Cel ten mógłby zostać osiągnięty poprzez zastosowanie w praktyce optymalnego modelu funkcjonowania sektora publicznego, w którym poza przepisami prawnymi, kluczową rolę odgrywają postawy i wartości moralne, edukacja oraz przejrzystość (jawność materialna). Artykuł prezentuje wyniki badań ankietowych, które umożliwiły identyfikację barier w uczeniu się obywateli kontroli społecznej wydatków publicznych zaprezentowanych we wnioskach.

Słowa kluczowe: przejrzystość; moralność; bariery w uczeniu się; wydatki publiczne; decyzje finansowe. 


\begin{abstract}
The difficulties in the effective implementation of the performance budgeting in Poland has become the starting point for the research presented in this paper. Despite over twenty years of experience in this field, it is difficult to say that public spending are effective, efficient and economical. We consider that this objective could be achieved by applying the optimal model of the functioning of public sector in practice. The model where, apart legal provisions, the moral attitudes and values, education and transparency play the crucial role. Thus the paper presents the results of the online survey, which enabled the identification of learning disabilities in citizens' control of public expenditure presented in conclusions.
\end{abstract}

Keywords: transparency; integrity; learning disabilities; public spending; financial decisions.

\title{
1. Uwagi wprowadzające
}

Postawy i wartości moralne, edukacja oraz przejrzystość (jawność materialna) ${ }^{1}$ zgodnie z założeniami modelu optymalnego funkcjonowania sektora publicznego (wykres 1) powinny, poza przepisami prawnymi, odgrywać istotną rolę w decydowaniu o środkach publicznych.

Istnienie w praktyce optymalnego modelu funkcjonowania sektora publicznego mogłoby zapewnić efektywne, skuteczne i gospodarne wydatkowanie środków publicznych. Choć powyższa, tzw. zasada 3E (ang. efficiency, effectivness, economy) stanowi trzon budżetu zadaniowego, wdrażanego w Polsce od ponad 20 lat, trudno znaleźć osobę, która zgodziłaby się z poglądem, że pieniądze publiczne w Polsce są wydatkowanie efektywnie, skutecznie i gospodarnie. Problemy ze skutecznym wdrożeniem budżetu zadaniowego w Polsce stały się punktem wyjścia do rozpoczęcia badań nad rolą moralności, przejrzystości i edukacji w podejmowaniu decyzji finansowych, co

1 Artykuł stanowi kontynuację rozważań zaprezentowanych w artykule: J.M. Salachna, M. Tyniewicki, Moralność jako element podejmowania decyzji finansowych w sektorze publicznym, „Prawo Budżetowe Państwa i Samorządu” 2016, nr 3(4), s. 9-23. Natomiast całościowe, dotychczasowe wyniki badań zespołu w tym zakresie zostały zaprezentowane przez U.K. Zawadzką-Pąk na dorocznym kongresie European Group for Public Administration (EGPA) w Utrechcie (Holandia) w 2016 r. (J.M. Salachna, U.K. Zawadzka-Pąk, M. Tyniewicki, E. Lotko, Politicians' Motivation for Implementation of Performance Management in New Democracies: a Case Study of Poland). 
w szerszym kontekście może mieć również doniosłe znaczenie z punktu widzenia funkcjonowania całego sektora publicznego.

Decyzje w zakresie wydatków publicznych, są podejmowane - nawiązując do teorii mocodawcy-agenta ${ }^{2}$ - przez decydentów politycznych (agentów) z upoważnienia przekazanego im w wyniku wyborów przez obywateli (mocodawcę). Jednakże ze względu na rozbieżność interesów obu powyższych grup oraz zniekształcenia informacji udostępnianych obywatelom konieczne staje się stworzenie mechanizmów skutecznej odpowiedzialności agentów przed mocodawcą.

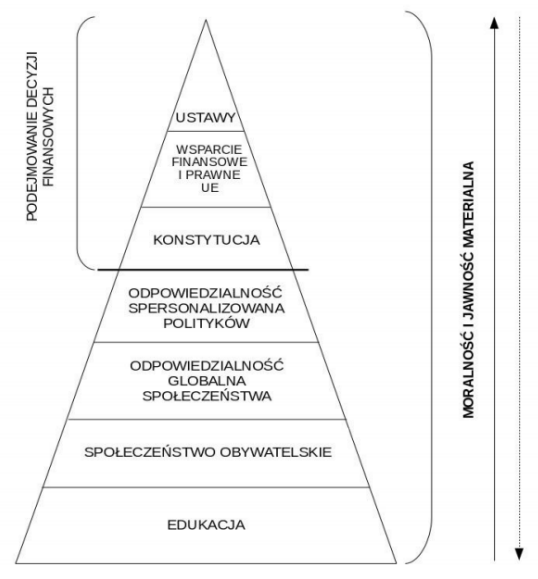

Wykres 1. Determinanty optymalnego modelu funkcjonowania sektora publicznego.

Źródło: opracowanie przez zespół: J.M. Salachna, M. Tyniewicki, U.K. Zawadzka-Pąk, E. Lotko.

Teoria mocodawca-agent pierwotnie została opracowana na potrzeby sektora prywatnego, w którym, jak ustalili jej twórcy, udział menadżerów we własności firmy (przedsiębiorstwa) ma pozytywny wpływ na zgodność interesu menadżerów z interesem właścicieli. W konsekwencji czynnikiem motywującym agentów do efektywnej i skutecznej pracy na rzecz firmy jest przekazanie im części jej udziałów ${ }^{3}$. Problem własności jest bardziej złożony do rozwiązania w sektorze publicznym, gdzie zrekonstruowanie stosunków

właścicielskich jest niezwykle trudne, o ile w ogóle możliwe.

Pewnym krokiem w tym kierunku może być wspięcie się na zaproponowaną przez B. Damgaarda i J.M. Lewisa ${ }^{4}$ „drabinę partycypacji”. Składa

\footnotetext{
S. Gailmard, Accountability and Principal-Agent Theory [w:] M. Bovens, R.E. Goodin, T. Schillemans (red.), The Oxford Handbook of Public Accountability, Oxford University Press 2014, s. 92-96.

3 M. Jensen, W. Meckling, Theory of the firm: managerial behavior, agency costs and ownership structure, „Journal of Financial Economics” 1976, nr 3 (4), s. 305-360.

4 B. Damgaard, J.M. Lewis, Accountability and Citizen Participation [w:] M. Bovens, R.E. Goodin, T. Schillemans (red.), The Oxford Handbook of Public Accountability, Oxford University Press, 2014, s. 92-96.
} 
się ona z pięciu szczebli, którymi - zaczynając od najniższego - są: edukacja, zaangażowanie, doradzanie, współpraca, wspólna własność.

Jednak, jak wykazał P. Senge ${ }^{5}$, istnieją uniwersalne dla każdej organizacji bariery w uczeniu się (ang. learning disabilities) ${ }^{6}$. Są one także przyczyną trudności w „uczeniu się” partycypacji społecznej, a tym samym budowania społeczeństwa obywatelskiego. Tymczasem jego istnienie jest niezbędnym warunkiem rzeczywistej odpowiedzialności agenta (decydentów politycznych) przed mocodawcą (obywatelami).

Wnioskując zatem z powyższego, pokonanie barier w uczeniu się partycypacji społecznej powinno umożliwić wejście na pierwszy szczebel wspomnianej drabiny, tj. edukację obywateli, zaś w dalszej konsekwencji - w warunkach sprzyjającej moralności i przejrzystości - osiągnąć najwyższy szczebel tej drabiny, tj. wspólną własność. Z kolei osiągnięcie tego szczebla przypuszczalnie powinno przyczynić się do rozwiązania, przynajmniej częściowego, problemu braku odpowiedzialności agenta wobec mocodawcy w sektorze publicznym.

\section{Rola postaw, wartości moralnych, edukacji i przejrzystości w interesowaniu się obywateli wydatkowaniem środków publicznych}

Uzasadnieniem podjęcia badań zaprezentowanych w niniejszym artykule stały się przeprowadzone przez zespół badawczy ${ }^{7}$ ilościowo-jakościowe badania przeprowadzone przy wykorzystaniu internetowej ankiety ${ }^{8}$. Zde-

5 P. Senge, The Fifth Discipline: The Art and Practice of the Learning Organization, New York 1990, s. 17-21.

6 Barierami w uczeniu się według P. Sengego są: 1. „Zajmuję się tylko swoim zakresem obowiązków”; 2. „Wróg jest gdzie indziej”; 3. Iluzja brania odpowiedzialności; 4. Koncentrowanie się na pojedynczych wydarzeniach; 5. Metafora gotującej się żaby; 6. Iluzja uczenia się z doświadczenia; 7. Iluzja zgranego zespołu kierowniczego. Istota tych barier oraz ich przykłady w kontroli społecznej wydatkowania środków publicznych zaprezentowano na zakończenie artykułu.

7 W skład zespołu badawczego wchodzili: J.M. Salachna, M. Tyniewicki, U.K. Zawadzka-Pąk, E. Lotko.

8 Szczegóły dotyczące przeprowadzonych badań opublikowano w: J.M. Salachna, M. Tyniewicki, Moralność jako element..., s. 15-16. 
cydowana większość respondentów (76\%) stwierdziła, iż potrzebne są zmiany w zakresie wydatkowania pieniędzy publicznych. Powyższe przekonanie wynika z faktu, że efekty obecnego, tradycyjnego budżetowania, jedynie uzupełnionego elementami budżetu zadaniowego nie są zadowalające i konieczne jest poszukiwanie sposobu skutecznego wdrożenia instrumentów zwiększających przejrzystość wydatkowania środków publicznych.

Choć nie ulega wątpliwości, że informacje na temat przeznaczenia wydatków publicznych powinny być zrozumiałe przede wszystkim dla polityków (81\% ankietowanych potwierdziło, że posiadanie wiedzy w zakresie wydatków publicznych przez polityków jest konieczne, zaś 18\%, że jest ewentualnie pożądane), to jednak również obywatele powinni rozumieć informacje na temat wydatków publicznych, gdyż przejrzystość informacji - podobnie jako moralność - jest warunkiem edukacji obywatelskiej i kształtowania społeczeństwa obywatelskiego. Tymczasem uzyskane wyniki potwierdziły nasze przypuszczenia, że informacje na temat wydatkowania pieniędzy publicznych w Polsce nie są wystarczająco przejrzyste. W ten sposób odpowiedziało 78\% respondentów, jedynie $12 \%$ było przeciwnego zdania.

Uzyskane odpowiedzi na dwa kolejne pytania pozwoliły stwierdzić, iż współudział obywateli w motywowaniu polityków do skutecznego i efektywnego wydatkowania środków publicznych jest potrzebny. Odpowiadając na pytanie o zasadność wpływu obywateli na decyzje polityków dotyczące wydatkowania środków publicznych, aż 83\% respondentów stwierdziło, że obywatele powinni mieć wpływ w tym zakresie, zaś zdaniem 15\% ankietowanych - mogą mieć wpływ. Z kolei na pytanie o podmiot, który powinien kontrolować polityków w wydatkowaniu pieniędzy publicznych (ankietowani mogli udzielić maksymalnie 2 odpowiedzi), choć najwięcej respondentów (72\%) uznało, że taką kontrolą powinny zająć się apolityczne wyspecjalizowane agencje publiczne, to jednak ponad połowa (51\%) wybrała grupy/stowarzyszenia/organizacje obywateli. Jedynie 20\% uczestników badania wskazało na rząd, zaś 8\% na firmy prywatne.

Poszukując przyczyn braku zainteresowania obywateli wydatkowaniem środków publicznych, zadaliśmy respondentom pytanie o charakte- 
rze otwartym ${ }^{9}$. Aż 59\% uzyskanych odpowiedzi dotyczyło szeroko rozumianych postaw i wartości moralnych (w tym 53\% obywateli, 4\% polityków i $2 \%$ mediów), 27\% - edukacji (26\% obywateli i 1\% dziennikarzy), zaś $14 \%$ - przejrzystości. Powyższe wyniki, z tym że w ujęciu bardziej szczegółowym, zaprezentowano na poniższym wykresie.

Wykres 2. Przyczyny braku zainteresowania obywateli wydatkowaniem środków publicznych.
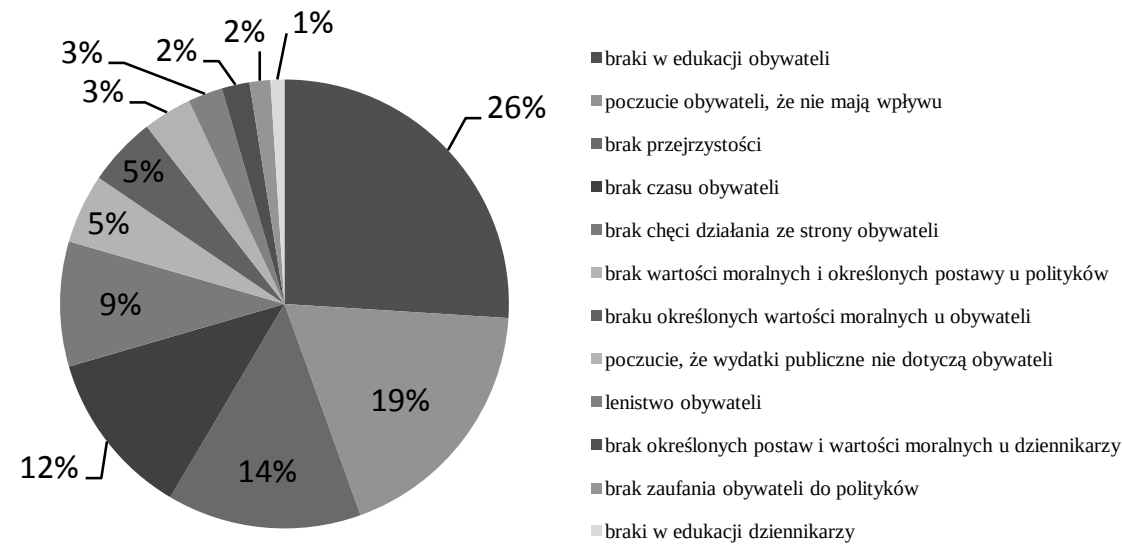

Źródło: opracowanie własne na podstawie przeprowadzonych badań ankietowych.

\section{Wpływ postaw, wartości moralnych oraz edukacji na przejrzystość wydatkowania środków publicznych}

Warunkiem kontroli obywatelskiej skuteczności, efektywności i gospodarności w wydatkowaniu środków publicznych jest niewątpliwie przejrzystość. Skoro natomiast informacje na temat wydatkowania pieniędzy publicznych nie są zrozumiałe dla obywateli, co potwierdziło $78 \%$ respondentów, zapytaliśmy o przyczyny nieujawniania przez polityków

9 Jedynie trzy osoby nie zgodziły się z wynikającym z pytania założeniem, że obywatele nie interesują się wydatkowaniem środków publicznych; niektórzy respondenci wskazali na więcej niż jedną przyczynę, stąd wyodrębniono 271 odpowiedzi na to pytanie, co potraktowano jako $100 \%$. 
zrozumiałych dla przeciętnego człowieka informacji na temat wydatkowania pieniędzy publicznych ${ }^{10}$. 89\% odpowiedzi dotyczyło szeroko rozumianych postaw i wartości moralnych (w tym aż 86\% postaw i wartości moralnych polityków i 3\% obywateli), zaś 11\% dotyczyło edukacji (8\% polityków i 3\% obywateli). Dokonując bardziej szczegółowej analizy powyższych wyników, należy stwierdzić, co następuje.

Po pierwsze, wśród postaw i wartości moralnych polityków najczęściej (30\%) podawano szeroko rozumiane korzyści polityczne takie jak: chęć uniknięcia zdecydowanych reakcji społeczeństwa, tj. wyciągania konsekwencji, kontroli, buntu, krytyki, sprzeciwu, a w konsekwencji również dbanie o własny spokój, chęć przypodobania się wyborcom (obawa przed utratą poparcia), własny interes finansowy. Kolejne $16 \%$ ankietowanych wskazało, że nieujawnianie przejrzystych informacji jest spowodowane lekceważeniem społeczeństwa pod pretekstem braku odpowiedniej specjalistycznej wiedzy u obywateli bądź brakiem zainteresowania z ich strony. Ponadto 14\% respondentów wskazało chęć ukrycia wydatków dokonywanych niezgodnie z przeznaczeniem (marnotrawionych) oraz zatajenie prowadzonych przez polityków działań, najczęściej niezgodnych z prawem. Cytując wypowiedź jednego z pracowników administracji, przejrzyste informacje „w sposób oczywisty odsłaniałyby nieudolność w wydatkowaniu grosza publicznego, z kolei inny z stwierdził, że transparentność wydatków nie leży w interesie polityków jako klasy rządzącej. Udostępnienie takich danych oznacza dzielenie się z obywatelami cennym zasobem, jakim jest realna wiedza o stanie i funkcjonowaniu państwa. Większa świadomość obywateli może być motorem bardziej intensywnego monitorowania władzy, patrzenia jej na ręce, formułowania krytyki”. Respondenci wskazali również, iż zachowanie polityków wynika z niskiej kultury politycznej (8\%), na którą zdaniem ankietowanych składa się przeświadczenie polityków o swojej nieomylności, brak chęci i czasu, braku ustawowego obowiązku i odpowiedzialności. Następnie,

10 Trzech ankietowanych nie podało przyczyn takiego zachowania polityków, z kolei niektórzy respondenci wskazali więcej niż jedną przyczynę, inni natomiast pominęli w ogóle pytanie, stąd wyodrębniono 218 odpowiedzi na to pytanie, co podobnie jak w przypadku poprzedniego pytania będziemy traktować jako $100 \%$. 
w 4\% odpowiedzi ankietowani zwrócili uwagę, iż politycy przedstawiając nieprzejrzyste, często nieprawdziwe dane, bazują na niewiedzy i nieświadomości obywateli (de facto swoich wyborców) i tym samym w łatwy sposób manipulują danymi dotyczącymi stanu finansów publicznych. Przykładowo jeden z pracowników administracji stwierdził, że „w ten sposób politycy łatwo mogą manipulować opinią społeczną, zaś brak konkretnych danych oznacza, że można ludziom wmówić wszystko”. Wreszcie $1 \%$ respondentów uznało, że decydujące znacznie ma brak wpływu obywateli na dokonywanie wydatków publicznych.

Po drugie, w kwestii postaw i wartości moralnych obywateli, respondenci zwrócili uwagę na dwa aspekty: brak zainteresowania, na co przeznaczane są pieniądze publiczne (2\%), i brak zaangażowania obywateli w sprawy społeczne (1\%).

Po trzecie, w zakresie edukacji polityków (11\%) dominującą odpowiedzią wśród respondentów jest brak specjalistycznej wiedzy polityków w zakresie finansów publicznych. Pozostali respondenci wskazali na brak świadomości nieposiadania odpowiednich kompetencji, nieumiejętność przekazywania informacji, brak świadomości czy chęci skorzystania z pomocy specjalistów.

Po czwarte, w kwestii braków w edukacji obywateli (3\%) zwrócono uwagę na: trudności obywateli w zrozumieniu podstawowych informacji, a tym bardziej sposobu wydatkowania pieniędzy publicznych; stan wiedzy obywateli utrudniający sprawdzenie, czy rozumieją przedstawiane im informacje; brak świadomości wśród obywateli, że to oni ostatecznie ponoszą konsekwencje politycznych decyzji; niechęć obywateli do zapoznawania się ze skomplikowanymi informacjami.

\section{Czynniki wpływające na przejrzystość informacji o wydatkowaniu środków publicznych}

Poznawszy motywację, którą kierują się politycy, nie ujawniając obywatelom przejrzystych informacji, zapytaliśmy respondentów o czynniki, które 
mogą zmotywować polityków do ujawniania takich informacji ${ }^{11}$. Ponad połowa odpowiedzi (61\%) dotyczyła spersonalizowanej odpowiedzialności polityków, 23\% postaw i wartości moralnych (20\% obywateli i 3\% polityków), zaś $5 \%$ edukacji (4\% obywateli i 1\% polityków). Zwrócić również należy uwagę, że aż 11\% respondentów stwierdziło, że nic nie można zmotywować polityków do prezentowania przejrzystych informacji, jeden z obywateli stwierdził, że „nie ma takiej siły w obecnych realiach”. Zaznaczyć należy, że choć głównym czynnikiem motywującym okazała się odpowiedzialność spersonalizowana polityków, oparta przede wszystkim o system kar, to jednak ze względu na niemożliwość, a przynajmniej poważną trudność wprowadzenia ustawowego obowiązku zamieszczania przejrzystych informacji, ze względu na potencjalnie bardzo duże trudności w ocenie, którą informację należy uznać za przejrzystą, zastosowanie wymienionych przez respondentów (różnego rodzaju) kar nie wydaje się możliwe.

Powyższy wynik statystyczny trafnie, choć nieświadomie, „streścił” jeden z pracowników administracji publicznej, stwierdzając, że „(...) istnieją dwie metody motywowania polityków w tej sferze. Pierwsza jest związana z motywacją wewnętrzną - rządzący muszą sami zrozumieć potrzebę i sensowność udostępniania takich informacji. Najprostszym sposobem osiągnięcia tego stanu jest wymiana elit, tzn. zastąpienie osób niechętnych transparentności życia publicznego - innymi, nowymi politykami. Jest to proces długotrwały, niekiedy trwający pokoleniami. Drugą metodą jest zewnętrzne motywowanie do ujawniania informacji o wydatkach. Może mieć ono formy nałożenia prawnego obowiązku ujawniania takich danych lub wprowadzenia sankcji za ich nieujawnianie. Wszystkie te zewnętrzne działania bazują na zewnętrznym przymusie wywieranym na rządzących, z czym wiążą się obiektywne trudności. Po pierwsze, zewnętrzny przymus może mieć formę normatywną. Ale zmiana prawa wymaga woli ustawodawcy - czyli samej klasy politycznej. Po drugie, zewnętrzny przymus może być wywierany przez społeczeństwo. Ale musi

11 Na tak sformułowane pytanie odpowiedzi nie było w stanie udzielić trzech respondentów. Inni wskazali więcej niż jedną odpowiedź, niektórzy natomiast w ogóle pominęli pytanie, nie udzielając żadnej odpowiedzi, stąd wyodrębniono 231 traktowane jako 100\%. 
być ono najpierw zainteresowane transparentnością wydatków - w mojej ocenie w warunkach polskiego społeczeństwa nie jest to najważniejsze z oczekiwań wobec władzy”.

Poniższy wykres zawiera zestawienie przyczyn nieujawniania przez polityków przejrzystych dla przeciętnego obywatela informacji na temat wydatkowania środków publicznych.

Wykres 3. Czynniki motywujące polityków do przedstawiania przejrzystych informacji.

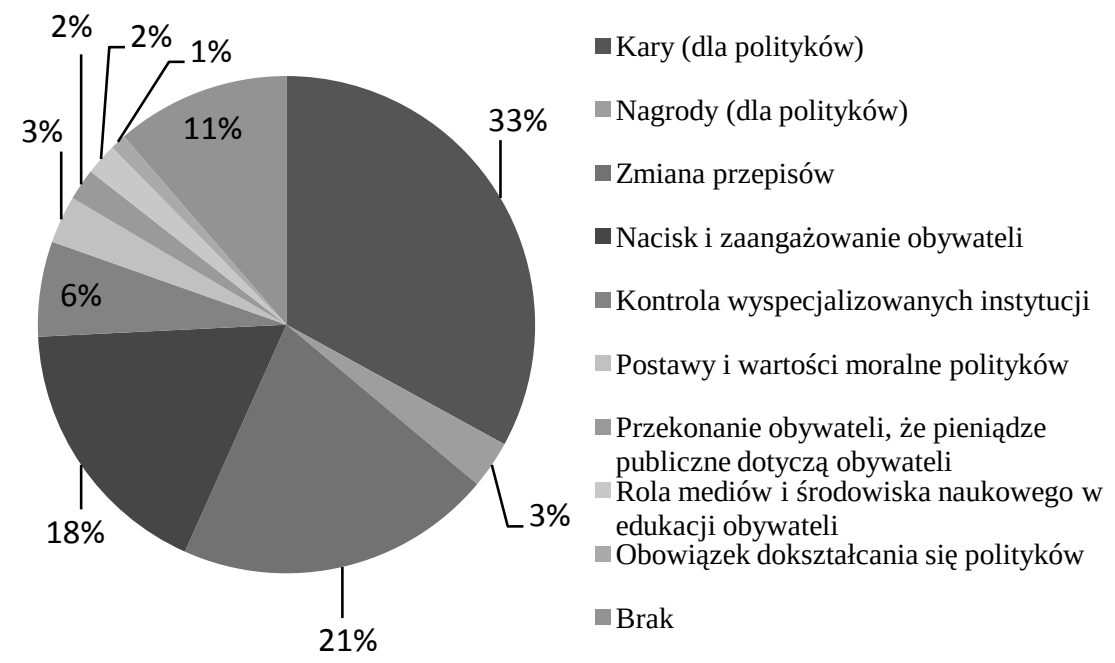

Źródło: opracowanie własne na podstawie przeprowadzonej ankiety.

\section{Analiza wyników}

Analiza odpowiedzi respondentów umożliwiła dokonanie wstępnej weryfikacji modelu optymalnego funkcjonowania sektora publicznego w zakresie wydatkowania środków publicznych. Jak wynika z poniższego zestawienia, zarówno edukacja, postawy, jak i wartości moralne oraz przejrzystość mogą mieć wpływ na optymalne wydatkowanie środków publicznych. 
Wykres 4. Zestawienie czynników wpływających na wydatkowanie środków publicznych.

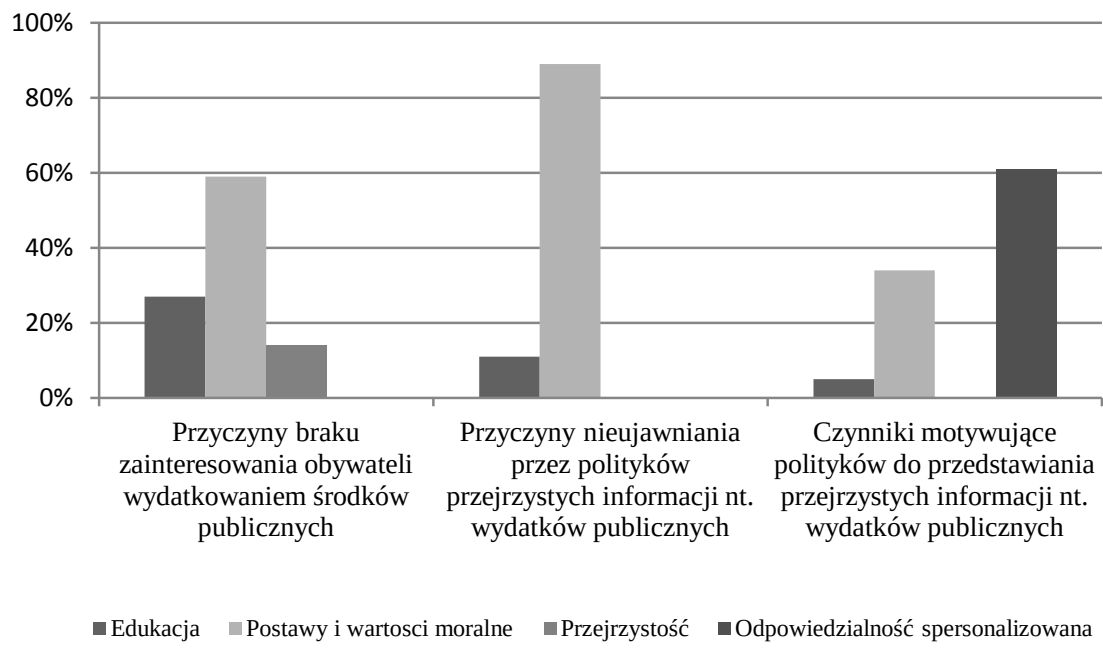

Źródło: opracowanie własne na podstawie przeprowadzonej ankiety.

Nie ulega wątpliwości, że zadanie respondentom dodatkowo innych pytań mogłoby zmienić częstotliwość pojawiających się odpowiedzi odnoszących się do moralności, przejrzystości i edukacji bądź też wykazać istnienie jeszcze innych czynników odgrywających istotną rolę w podejmowaniu decyzji finansowych. Jednakże uzyskane wyniki wydają się potwierdzać nie tylko potrzebę szerszej analizy przejrzystości będącej tradycyjne w obszarze zainteresowań nauki prawa finansowego, ale również edukacji obywatelskiej oraz moralności. Interdyscyplinarna analiza wydatków publicznych nie tylko z perspektywy prawa, ale również psychologii (motywacji polityków), etyki (zasad moralnych) oraz socjologii (funkcjonowania społeczeństwa) mogłaby przyczynić się do efektywniejszego, skuteczniejszego i gospodarniejszego wydatkowania środków publicznych. 


\section{Wnioski}

Zaproponowane powyżej interdyscyplinarne podejście badawcze do wydatkowania środków publicznych, choć będące jeszcze we wczesnej fazie prac, w wyniku którego dokonano analizy determinantów optymalnego modelu funkcjonowania sektora publicznego, umożliwiło identyfikację barier w uczeniu się obywateli społecznej kontroli wydatkowania środków publicznych. Uzyskane wyniki zaprezentowano w poniższej tabeli.

Tabela 1. Bariery w uczeniu się obywateli kontroli społecznej wydatkowania środków publicznych.

\begin{tabular}{|c|l|l|}
\hline $\begin{array}{c}\text { Nazwa bariery } \\
\text { w uczeniu się } \\
\text { wg P. Sengego }\end{array}$ & \multicolumn{1}{|c|}{$\begin{array}{c}\text { Istota bariery } \\
\text { w uczeniu się }\end{array}$} & $\begin{array}{l}\text { Przykłady bariery w uczeniu się partycy- } \\
\text { pacji społecznej wynikające z braku } \\
\text { przejrzystości }\end{array}$ \\
\hline $\begin{array}{l}\text { 1. „Zajmuję się } \\
\text { tylko swoim zakre- } \\
\text { sem obowiązków” }\end{array}$ & $\begin{array}{l}\text { Proces uczenia się jest } \\
\text { utrudniony poprzez wyłącz- } \\
\text { ne identyfikowanie się } \\
\text { z własnymi obowiązkami. }\end{array}$ & $\begin{array}{l}\text { Politycy, koncentrując się wyłącznie na swoich } \\
\text { obowiązkach służbowych”, nie widzą interesu } \\
\text { ujawnianiu przejrzystych informacji, } \\
\text { w konsekwencji obywatele nie mają możliwo- } \\
\text { ści sprawowania kontroli obywatelskiej nad } \\
\text { wydatkowaniem środków publicznych. }\end{array}$ \\
\hline $\begin{array}{l}\text { 2. „Wróg jest gdzie } \\
\text { indziej” }\end{array}$ & $\begin{array}{l}\text { Naturalną cechą człowieka } \\
\text { jest doszukiwanie się przy- } \\
\text { czyn niepowodzeń we } \\
\text { wszystkim i wszystkich } \\
\text { dookoła, nie zaś przyznanie } \\
\text { się do winy. }\end{array}$ & $\begin{array}{l}\text { Z jednej strony sami obywatele nie są zaintere- } \\
\text { sowani sposobem wydatkowania środków } \\
\text { publicznych, gdyż mają - słuszne skądinąd - } \\
\text { poczucie braku wpływu. Z drugiej strony, } \\
\text { jednym z powodów nieujawniania przez } \\
\text { polityków przejrzystych informacji jest ich } \\
\text { przekonanie o tym, że obywatele nie są }\end{array}$ \\
w stanie takich informacji zrozumieć.
\end{tabular}

12 Proces wdrażania budżetu zadaniowego w Polsce przez pryzmat barier w uczeniu się został zaprezentowany w: U.K. Zawadzka-Pąk, J.E. Kulikowska-Kulesza, E. Lotko, Towards performance culture via learning culture: lessons from Poland, „Ekonomia i Zarządzanie” 2015, vol. 7(4), s. 7-13; U.K. Zawadzka-Pąk, J.E. Kulikowska-Kulesza, E. Lotko, Towards performance culture via learning culture: lessons from Poland. Part II, artykuł w procesie recenzyjnym czasopisma „Ekonomia i Zarządzanie”. 


\begin{tabular}{|l|l|l|}
\hline & & $\begin{array}{l}\text { związanych z nadużyciami finansowymi. } \\
\text { Wyłączne skupienie się mediów na skandalicz- } \\
\text { nych przypadkach marnotrawienia środków } \\
\text { publicznych nie sprzyja edukacji obywateli. }\end{array}$ \\
\hline $\begin{array}{l}\text { 5. Metafora gotują- } \\
\text { cej się żaby }\end{array}$ & $\begin{array}{l}\text { Nieumiejętność dostrzegania } \\
\text { stopniowo narastających } \\
\text { zagrożeń. }\end{array}$ & $\begin{array}{l}\text { Nie jest możliwy skuteczny rozwój społeczeń- } \\
\text { stwa obywatelskiego, gdyż brakuje jego pod- } \\
\text { stawowych determinantów, tj. edukacji, przej- } \\
\text { rzystości, postaw i wartości moralnych. }\end{array}$ \\
\hline $\begin{array}{l}\text { 6. Iluzja uczenia się } \\
\text { poprzez doświad- } \\
\text { czenia }\end{array}$ & $\begin{array}{l}\text { Nie jest możliwe uczenie się } \\
\text { wyłącznie poprzez własne } \\
\text { doświadczenie, m.in. z tego } \\
\text { powodu, że konsekwencje } \\
\text { obecnych działań znane będą } \\
\text { dopiero w przyszłości. }\end{array}$ & $\begin{array}{l}\text { Sposobu społecznej kontroli wydatkowania } \\
\text { środków publicznych nie można nauczyć się } \\
\text { w Polsce, korzystając z wcześniejszych do- } \\
\text { świadczeń, gdyż do tej pory mobilizacja społe- } \\
\text { czeństwa obywatelskiego miała miejsce wy- } \\
\text { łącznie jako efekt oporu przeciwko władzy. } \\
\text { Dotychczasowa aktywność społeczeństwa } \\
\text { obywatelskiego nie była więc czynnikiem } \\
\text { trwale je zespalającym. }\end{array}$ \\
\hline $\begin{array}{l}\text { 7. Iluzja zgranego } \\
\text { zespołu kierowni- } \\
\text { czego }\end{array}$ & $\begin{array}{l}\text { Decydenci prowadzą między } \\
\text { sobą nieustanną walkę, } \\
\text { unikają decyzji, które mo- } \\
\text { głyby zaszkodzić ich wize- } \\
\text { runkowi, skrywają się za } \\
\text { wspólną strategią zespołu, } \\
\text { utrzymując w ten sposób } \\
\text { iluzję współpracy. }\end{array}$ & $\begin{array}{l}\text { Politycy niejednokrotnie podejmując decyzje } \\
\text { publiczne, tworzą fikcję dbania o wspólne } \\
\text { dobro; w rzeczywistości są motywowani } \\
\text { partykularnymi interesami, stąd brak przejrzys- } \\
\text { tych informacji w zakresie wydatkowania } \\
\text { środków publicznych. }\end{array}$ \\
\hline
\end{tabular}

Jak wynika z powyższej tabeli, bariery w uczeniu się społecznej kontroli wydatkowania środków publicznych dotyczą wszystkich omówionych w niniejszym artykule determinantów optymalnego modelu funkcjonowania sektora publicznego, tj. wartości moralnych, przejrzystości oraz edukacji. Wskazane przykłady barier w uczeniu partycypacji społecznej w Polsce z jednej strony świadczą o uniwersalności barier zidentyfikowanych przez wybitnego amerykańskiego naukowca, P. Sengego, z drugiej zaś strony uwidaczniają potrzebę głębszej refleksji nad sposobem wypracowania rozwiązań, które zapewnią optymalne funkcjonowanie sektora publicznego w Polsce. W konsekwencji szczególnego znaczenia nabierają postawy i wartości moralne (w tym troska o wspólne dobro, odpowiedzialność, gotowość do poświęcenia własnego czasu) zarówno obywateli, jak i decydentów politycznych, edukacja obu tych grup, a także będące pochodną powyższych determinantów: zewnętrzna i wewnętrzna motywacja polityków do ujawniania przejrzystych informacji oraz do korzystania $\mathrm{z}$ nich przez obie strony. $\mathrm{Z}$ kolei $\mathrm{w}$ węższym aspekcie sektora publicznego, a mianowicie w kontekście prawa finansowego i finansów 
publicznych wartości moralne, edukacja oraz przejrzystość mogłyby umożliwić urzeczywistnienie koncepcji odpowiedzialnego zarządzania finansami publicznymi (ang. responsible public finance management) ${ }^{13}$ rozumianej jako pobieranie dochodów publicznych oraz zarządzanie wydatkami publicznymi zgodnie z zasadami równowagi, skuteczności, efektywności, realizmu, uczciwości, przejrzystości oraz demokracji - wspierając partycypację społeczną oraz respektowanie demokratycznych procedur ${ }^{14}$.

\section{Bibliografia:}

Damgaard B., Lewis J.M., Accountability and Citizen Participation [w:] M. Bovens, R.E. Goodin, T. Schillemans (red.), The Oxford Handbook of Public Accountability, Oxford University Press, 2014.

Gailmard S., Accountability and Principal-Agent Theory [w:] M. Bovens, R.E. Goodin, T. Schillemans (red.), The Oxford Handbook of Public Accountability, Oxford University Press, 2014.

Jensen M., Meckling W., Theory of the firm: managerial behavior, agency costs and ownership structure, „Journal of Financial Economics” 1976, nr 3(4), s. 305-360.

Salachna J.M., Tyniewicki M., Moralność jako element podejmowania decyzji finansowych w sektorze publicznym, „Prawo Budżetowe Państwa i Samorządu" 2016, nr 3(4), s. 9-23.

Senge P., The Fifth Discipline: The Art and Practice of the Learning Organization, New York 1990.

Zawadzka-Pąk U.K., Kulikowska-Kulesza J.E., Lotko E., Towards performance culture via learning culture: lessons from Poland, „Ekonomia i Zarządzanie" 2015, nr 4(7), s. 7-13.

Zawadzka-Pąk U.K., Responsible Public Finance Management [w:] A. Farazmand (red.), Global Encyclopedia of Public Administration, Public Policy, and Governance, Springer 2017 (w druku).

13 U.K. Zawadzka-Pąk, Responsible Public Finance Management [w:] A. Farazmand (red.), Global Encyclopedia of Public Administration, Public Policy, and Governance, Springer 2017 (w druku).

14 Składamy serdeczne podziękowania wszystkim, którzy zechcieli wziąć udział w badaniu ankietowym. 